\title{
Genotyping of Kappa-Casein Gene of Buffalo in Indonesian
}

\author{
Margawati ET ${ }^{1}$, Volkandari $\mathrm{SD}^{1}$, Indriawati ${ }^{1}$, Talib $\mathrm{C}^{2}$ \\ ${ }^{1}$ Research Center for Biotechology of Indonesian Institute of Sciences \\ Jl. Raya Bogor Km. 46, Cibinong, Bogor 16911, West Java, Indonesia \\ ${ }^{2}$ Indonesian Research Insitute for Animal Production \\ PO Box 221, Bogor 16002, West Java, Indonesia \\ enda032@lipi.go.id; endangtri@hotmail.com
}

\begin{abstract}
Casein $(\mathrm{KCN})$ is a milk protein with four variants of alpha S1, alpha S2, beta and kappa which has different allel of each. Kappa Casein (CSN3) gene lies at exon 4 associating with fat and protein milk contens. Genetic variation of CSN3 gene influences quality and composition of milk. The aim of this research was to genotype the CSN3 gene of Bufalos from several places in Indonesia. Amount of 29 buffalo samples was used in this research, those consisted of 15 collected from Medan, 3 samples of Banyuwangi, 10 samples of Baluran and one sample of South-East Nusa Tenggara (NTT). A Polymerase Chain Reaction-Restiction Fragment Length Polymorphism (PCRRFLP) method was used for CSN3 gene analysis. The CSN3 gene was amplified at $56^{\circ} \mathrm{C}$ of annealing with 30 cycles and resulted a right fragment of $379 \mathrm{bp}$. The fragments were digested with HindIII at $37^{\circ} \mathrm{C}$ during for four hours for genotyping analysis. The result showed that $\mathrm{BB}$ genotypes were found at the locus of CSN3 gene in all samples. Those BB genotypes merged the pattern of digested fragments with sizes of 255 and $154 \mathrm{bp}$. This finding suggests that genotyping using HindIII reveals monomorphics of BB types accociated with milk content of casein.
\end{abstract}

Key Words: KCN Gene, Genotyping, PCR-RFLP, Indonesian Buffalo

\section{INTRODUCTION}

Indonesia is known as a country with its mega biodiversity among species, breed and population in term of animal genetic resources (FAO 2013). Domesticated ruminant animals have been contributing to this country in supplying of protein both from meat and milk sources. Up to present, protein consumption of people is dominated by cattle and not popular yet fulfilled by milk either from goat or buffalo. In 2014, buffalo population in Indonesia is very low $(1,320,616)$ compared to cattle $(14,703,000)$ population (DGLSAH 2014). Both buffalo and cattle have a chance to contribute both in meat and milk consumption, however buffalo has not been exposed yet.

Up to present Indonesia still imports 30\% meat and 60\% milk (FAO 2013). Milk production in catle is higher than in Buffalo. Lactation period in cattle is up to 305 days (Syrstad 1993) with dry period of 40-50 days (Univ. Illionis 2010) while in buffalo is lower (262-295 days) with a longer dry period of 2-3 months (Tamil Nandu Univ. 2009). Even though a lower milk production in buffalo than in catle, however chemical contents of buffalo milk is higer than in cattle (Damayanthi et al. 2014). Therefore, milk buffalo has a prospect in future as a source of better milk quality. Milk protein components in river buffalo is higher (Damayanthi et al. 2014) compared to cattle (Susilorini \& Sawitri 2007; Pandey \& Voskuil 2011). As reported by Damayanthi et al. (2014) that protein milk content of swamp buffalo is higher $(5.14 \pm 0.37 \%)$ than in river buffalo $(4.68 \pm 0.41 \%)$.

Milk is an important source of essential nutrients besides for lactating calves it also as a key raw material for human food preparations (Reinhardt et al. 2012). All over the world people fulfill approximately $13 \%$ of their protein requirements from milk and dairy products. Indonesian buffalo has not been explored yet to improve their genetic merit for milk traits. In the context of achieving self-sufficient of meat and milk in Indonesia, 
buffalo needs to be explored for their potential in both meat and milk production traits. Milk production relates to protein contents. Milk protein is important trait since influences the milk quality.

Milk protein is divided into two fractions, those are soluble protein named whey protein with constitutes of $\alpha$-Lactoalbumin and $\beta$-lactoglobulin. Another is insoluble fraction named casein which has four variants, i.e., $\alpha-S 1, \alpha-S 2, \beta$-casein and kappa casein (El-Rafey \& Darwish 2007; Dogru et al. 2007; Rachagani \& Gupta 2008; Deb et al. 2014). Kappa casein (CSN3) is one of the most important milk proteins that controlled by a gene with 5 exon and 4 intron, the CSN3 protein has 19,8 $\mathrm{kDa}$ molecular weight and 169 amino acids (Abassi et al. 2009). The kappa casein gene lies at chromosome 6 of bovine and at chromosome 4 of sheep and goat. Casein fraction of milk proteins significantly influences the composition and physic-chemical properties of milk (Grosclaud 1988) and milk production (Ghafoor et al. 2014).

Breakhtrugh in molecular genetics, it contributes animal breeders that have greatly and effectively manipulated the genomes of livestock and enhanced production traits in their herds by selecting individuals with superior traits. Those selected individuals are as sources for the next generations. Therefore, there is a need to use selection methods with based on genomic studies (André 2012). Genes associating with performance parameters can improve the estimation of breeding value and hence can contribute as a suitable inputs for conventional breeding procedures. Genotyping or genetic polymorphism relates to the differences in animal performance, it can be taken into account in the selection process.

This CSN3 gene is important to be explored for looking the best casein content in milk buffalo. Therefore this study was designed to focus on genotyping of kappa casein gene in several Indonesian buffalos to find the best buffalo bearing the gene with marker technology approach. This information is necessary for selection process of the gene relating to the casein content and buffalo milk production based on genomic study.

\section{MATERIAL AND METHODS}

\section{Blood sample collection}

Fresh blood samples were collected from base point of tails. Amout of 29 buffalo (river and swamp) originated from several places in Indonesia. The blood was collected in $5 \mathrm{ml}$ per head by a $21-\mathrm{G}$ needle into a vacuumed-tube containing EDTA. Those 29 buffaloes samples were originated from Medan (15), Banyuwangi (3), Baluran (10), and one sample from East Nusa Tenggara (NTT), see Table 1.

Table 1. List of Indonesian buffalo samples used in the research

\begin{tabular}{lccccc}
\hline \hline \multirow{2}{*}{$\begin{array}{l}\text { Buffalo } \\
\text { (Bubalus bubalis })\end{array}$} & $\begin{array}{c}\text { Number } \\
\text { (head) }\end{array}$ & $\begin{array}{c}\text { Medan } \\
\text { (Sumatra) }\end{array}$ & $\begin{array}{c}\text { Banyuwangi } \\
\text { (East Java) }\end{array}$ & $\begin{array}{c}\text { Baluran } \\
\text { (East Java) }\end{array}$ & $\begin{array}{c}\text { East Nusa } \\
\text { Tenggara }\end{array}$ \\
\hline River $(2 \mathrm{n}=50)$ & 15 & $15(3 \mathrm{M} ; 12 \mathrm{~F})$ & - & - & - \\
Swamp $(2 \mathrm{n}=48)$ & 14 & - & $3(2 \mathrm{M} ; 1 \mathrm{~F})$ & $10(1 \mathrm{M} ; 9 \mathrm{~F})$ & $1(\mathrm{M})$ \\
\hline Total & 29 & & & & \\
\hline
\end{tabular}

M: Male; F: Female 


\section{DNA extraction}

Genome DNA was manually extracted from the whole blood cells according to a method of Montgomery \& Sise (1990). Quality and concentration of the extracted DNA were measured through a spectofotometer of GenQuant Pro (Bioscience, USA). DNA concentration was calculated at $\lambda 260 \mathrm{~nm}$ wave length of absorbancy while DNA quality was calculated at $\lambda 260 / 280 \mathrm{~nm}$. DNA concentration was prepared at $50 \mathrm{ng} / \mu \mathrm{l}$ for PCR work.

\section{Polymorphism chain reaction}

Amplification of CSN3 gene (379 bp) was conducted by applying a pair of KCN primer for cattle (Mitra et al. 1998). Those sequence primers of KCN-F (5'CACGTCACCCA CACCCACATTTATC-3') dan KCN-R (5'-TAATTAGCCCAT TTCGCCTTCTCTGT-3'), see Figure 1. Total volume of $20 \mu \mathrm{l}$ containing $10 \mu \mathrm{l}$ PCR Master Mix of DreamTaq Green PCR Master Mix (2x), $1 \mu$ of $10 \mathrm{pmol} / \mu \mathrm{l}$ each primer, 6 $\mu \mathrm{LDW}$ and $2 \mu \mathrm{l}$ of $50 \mathrm{ng} / \mu \mathrm{l}$ DNA template was used as a PCR reaction. Amplification was carried out in a Thermalcycler (Eppendroft, USA) with following condition: predenaturation $95^{\circ} \mathrm{C}$ for $1 \mathrm{~min}$, denaturation $95^{\circ} \mathrm{C}$ for $1 \mathrm{~min}$, annealing $56^{\circ} \mathrm{C}$ for $1 \mathrm{~min}$, elongation $72^{\circ} \mathrm{C}$ for $1 \mathrm{~min}$, was repeated up to 30 cycles followed a final extension $72^{\circ} \mathrm{C}$ for $5 \mathrm{~min}$, then stepped down temperature up to $10^{\circ} \mathrm{C}$. PCR products were analyzed in $1 \%$ agarose gel at 100 volt for 1 hour, then immersed in Ethidium Bromide solution. Visualisation of bands used UV transilluminator (MUV21, MajorScience, USA) with a DNA ladder of VC $100 \mathrm{bp}$ Plus (Vivantis, USA).

\section{Restriction fragment length polymorphism}

PCR products were digested with restriction enzyme of HindIII (Fermentas, Germany), at SNP $353 \mathrm{~A}>\mathrm{C}$ (Figure 1). Final of $10 \mu \mathrm{l}$ reaction volume consisted of $5 \mu \mathrm{l}$ PCR products, $1 \mu \mathrm{l}$ of buffer R with 10x BSA (Fermentas), $0.2 \mu \mathrm{l}$ of 10 unit HindIII and $3.8 \mu \mathrm{l}$ of DDW. The reaction mixture was incubated at $37^{\circ} \mathrm{C}$ for four hours in a waterbath (Trade Raypa). Following incubation, the digested fragment was analyzed by electrophoresis in a $2 \%$ agarose gel and run with 100 volt for 1 hour then stained with Ethidium Bromide (AppliChem, Germany). The digested fragment (polymorphic locus) was compared with a 100 bp DNA ladder in $2 \%$ agarose gel. Bands were visualized with a UV transimulator exposure (MUV21, MajorScience, USA) to observe polymorphic locus, then documented by a digital camera (Nikon, Japan).

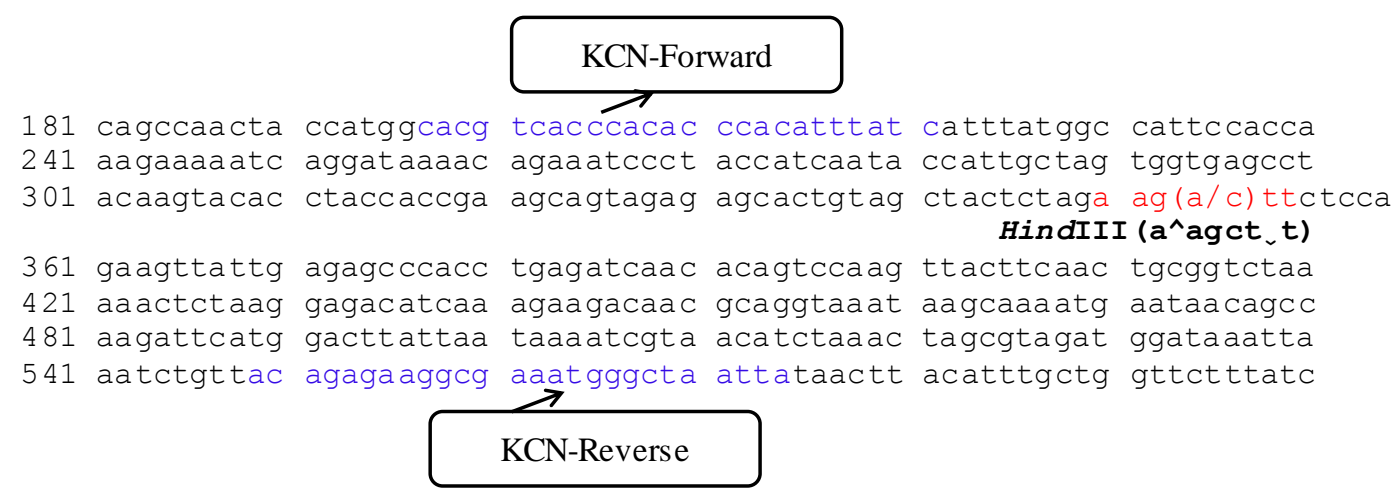

Figure 1.KCN primer sequence and restriction site of HindIII (SNP $353 \mathrm{~A}>\mathrm{C}$; red sign), based on GenBank AJ841946.1 


\section{RESULTS AND DISCUSSION}

\section{Kappa-casein gene}

Gene of kappa casein (CSN3) was detected in all buffalo samples with fragment size of $379 \mathrm{bp}$ (Figure 2). The length of CSN3 gene in this study is similar to CSN3 gene size reported in cattle (Mitra et al. 1998). This homology might be that buffalo is classified as the same family of Bovidae with subfamily Bovinae and tribe of Bovini (MacEachern et al. 2009).

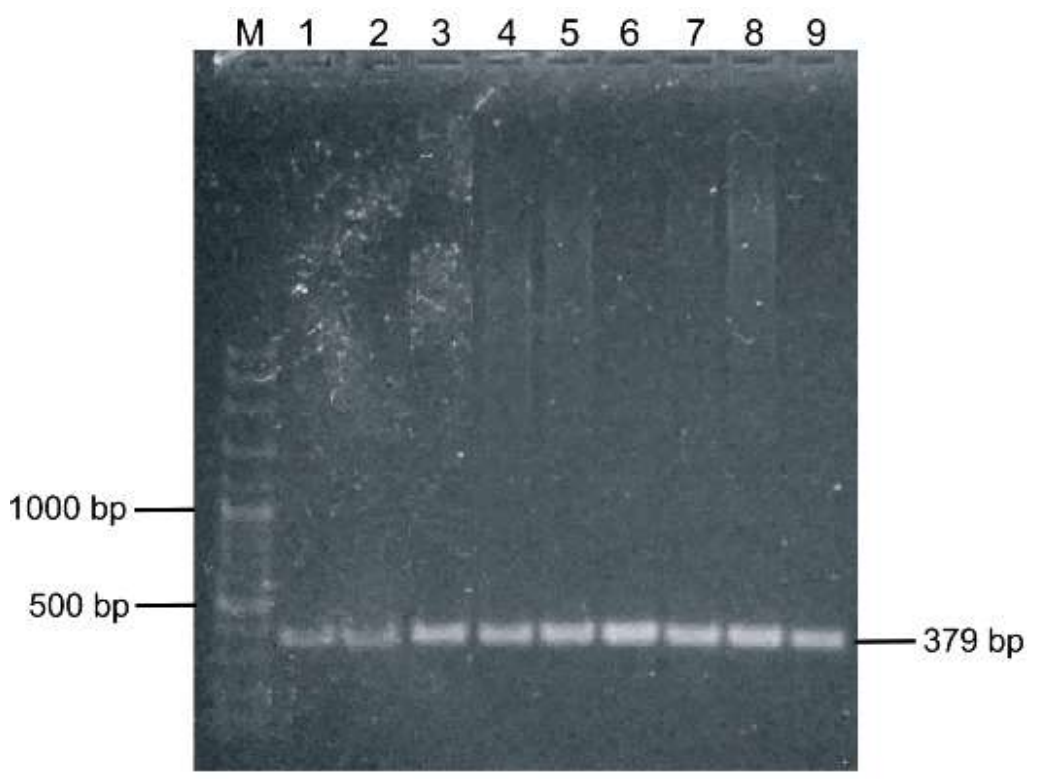

M: 100 bp DNA ladder; Line 2 to 9: Indonesian buffalo samples

Figure 2. Kappa-casein $(\mathrm{KCN})$ gene found in all buffalo samples at $379 \mathrm{bp}$

The KCN gene of bovine located at chromosome 6 p31 with full length of the gene is $13 \mathrm{~kb}$ (Othman et al. 2011). This variant of kappa casein gene locating at exon 4 has allel $\mathrm{A}$ and $\mathrm{B}$. The allel B was reported associating with the high content of protein and fat milk (Rachagani \& Gupta 2008; Gangaraj et al. 2008). The KCN gene is associated with the yield and component of milk. Caseins amount to nearly $80 \%$ of the protein output in cow milk (Patel et al. 2007a). Caseins are biologically important proteins and they are also a raw material for the cheese making industry (El-Gawad \& Ahmed 2011).

\section{Genotyping of KCN gene}

Genotyping of KCN gene digested by HindIII yielded 2 fragments of 154 bp and 225 $\mathrm{bp}$ in all samples (Figure 3A). Those fragment patterns were categorized as genotypes BB in all samples. None of genotype A found in this study which has fragment size of $379 \mathrm{bp}$ and different from genotype BB with 2 fragments (Figure 3B). Those fragments are termed as allels. This finding is different from cattle which has polymorphic for the kappa casein gene (Doosti et al. 2011; Khaizaran \& Al-Razem 2014; Cinar et al. 2016). 


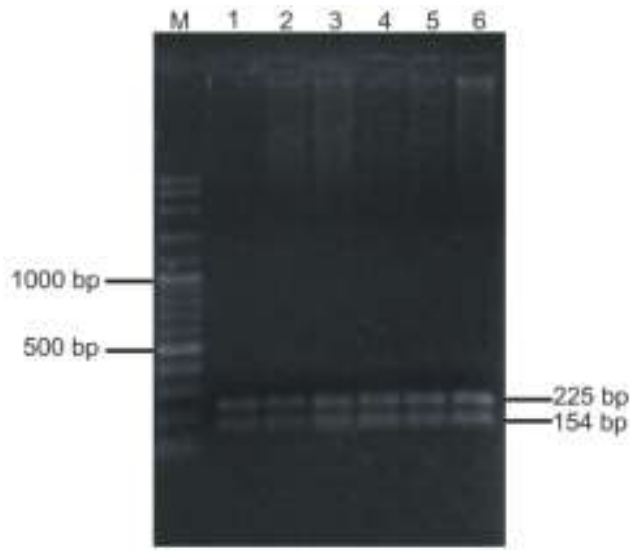

(A)

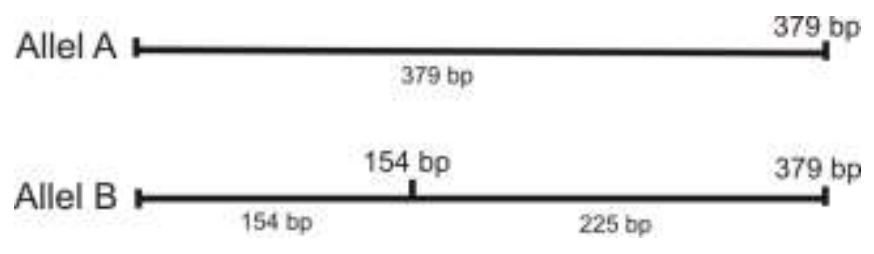

(B)

Figure 3. (A) Genotyping of KCN gene digested with HindIII (M: 100 bp DNA ladder; Line 1 to 6: Buffalo samples with BB genotypes); (B) Pattern of KCN genotypes: Allel A (379 bp) and Allel B (154 and 225 bp)

This finding of genotype BB in all buffalo samples (swamp and river) in Indonesia is similar to previous reports of allel frequencies which found in most of buffalo (Table 2).

Table 2. Allel frequencies of KCN gene in buffalos

\begin{tabular}{lcccc}
\hline \hline \multirow{2}{*}{ Breed of buffalo } & \multirow{2}{*}{ Origin of buffalo } & \multicolumn{2}{c}{ Allele frequencies } & \multirow{2}{*}{ References } \\
\cline { 3 - 4 } & Guangxi, China & 0 & 1 & Ren et al. (2011) \\
Water buffalo & Khouzestan, Iran & 0 & 1 & Abbasi et al. (2009) \\
Wiver buffalo & Egypt & 0.125 & 0.875 & Gouda et al. (2013) \\
Nili-Ravi buffalo & Pakistan & 0 & 1 & Ghafoor et al. (2014) \\
River buffalo & India & 0 & 1 & Gangaraj et al. (2008) \\
Pandharpuri buffalo & India & 0 & 1 & Shende et al. (2009) \\
River buffalo & Egypt & 0 & 1 & Dayem et al. (2009) \\
Murrah, Jaffarabadi, & India & 0.016 & 0.984 & Patel et al. (2007b) \\
Surti, Pandharpuri & & & & \\
River breed & Egypt & 0 & 1 & Dayem et al. (2009) \\
Nili-Ravi buffalo & Pakistan & 0 & 1 & Riaz et al. (2008) \\
Anatolian water buffalo & Turkey & 0 & 1 & Cinar et al. (2016) \\
Egyptian buffalo & Egypt & 0 & 1 & Othman et al. (2011) \\
\hline
\end{tabular}

This finding of genotype BB in the kappa casein gene is associated with protein content in milk. It was known that BB types have a significant influencing on cheese making properties (Shende et al. 2009). It was reported that genotype BB yields more protein than genotype $\mathrm{AB}$ and even more milk yields than genotype AA (Rachagani \& Gupta 2008; Azevado et al. 2008). As stated by El Nahas et al. (2013), types of BB are differing by mutation points in nucleotide sequence encoding amino acid 136 and $148 \mathrm{bp}$. Position of 136 which is thrionine (ACC) changed into isoleucin (ATC) and position of 148 is arpargine (GAT) changed into alanine (GCT) for A and B types, respectively. 
Observation of BB genotypes in all samples seems that there was no crossed with other buffalo breed in the most buffalo of Indonesia. It figures that most buffalo in Indonesia have a potential in a higher casein protein content of milk production.

\section{CONCLUSION}

A Kappa casein gene was amplified at the right size of 379 bp in all buffalo samples. All swamp and river buffalos used in this research showed monomorphic patterns of the kappa-casein gene with only had allel B and presented in homozygote of BB genotypes. It seems that most buffalo in Indonesia have a potential in a higher casein protein content of milk production. This finding contributes to the breeding program especially in milk protein content of buffalo.

\section{ACKNOWLEDGEMENT}

The research was partly supported by DIPA 2015 and 2016. Authors thank to Handrie and other field technicians who helped in blood collection and M Ridwan who assisted in laboratory works.

\section{REFERENCES}

Abbasi B, Fayazi J, Nasiri MTB, Roshanfekr HA, Mirzadeh KH, Sadr AS. 2009. Analysis of kappa casein gene polymorphism by PCR-RFLP in buffalo population in Khouzestan Province. Res J Bio Sci. 4:1073-1075.

André E. 2012. The development and application of genomic selection as a new breeding paradigm. Anim Front. 2:10-15.

Azevado LS, Nascimento CS, Steinberg RS, Carvalho RS, Peixoto CS, Teodoro RL, Machado MA. 2008. Genetic polymorphism of the kappa-casein gene in Brazilian cattle. Genet Res 7:623-630. DOI: http://dx.doi.org/10.4238/vol7-3gmr428.

Cinar MU, Akyuz B, Arslan K, Ilgar EG. 2016. Genotyping of the kappa-casein and betalactoglobulin genes in Anatolian water buffalo by PCR-RFLP. Int J Dairy Technol. 69:308311.

Damayanthi E, Yopi, Hasinah H, Setyawardani T, Rizqiati H, Putra A. 2014. Characteristics of water and swamp buffalo milk in North Sumatra. J Ilmu Pertanian Indonesia. 19:67-73.

Dayem AMHA, Mahmoud KGHM, Nawito MF, Ayoub MM, Darwish SF. 2009. Genotyping of kappa-casein gene in Egyptian buffalo bulls. Livest Sci. 122:286-289. DOI: 10.1016/j.livsci.2008.09.010

Deb R, Singh U, Kumar S, Singh R, Sengar G, Sharma A. 2014. Genetic polymorphism and association of kappa-casein gene with milk production traits among Frieswal (HF $\times$ Sahiwal) cross breed of Indian origin. Iranian J Vet Res. 15:406-408.

University of Ilionis. 2010. Dry period in dairy cattle [internet]. [cited 11 April 2016]. Available from: http://ansci.illionis.edu/static/ansc438/ Lactation/dryperiod.html.

DGLSAH. 2014. Livestock and animal health statistics 2014. Jakarta (Indonesia): Directorate General of Livestock and Animal Health, Ministry of Agriculture Indonesia.

Doosti A, Arshi A, Vatankhah M, Amjadi A. 2011. Kappa-casein gene polymorphism in Holstein and Iranian native cattle by polymerase chain reaction restriction fragment length polymorphism (PCR-RFLP). African J Biotechnol. 10:4957-4960. 
El-Nahas SM, Bibars MA, Taha DA. 2013. Genetic characterization of Egyptian buffalo CSN3 gene. J Genet Eng Biotechnol. 11:123-127.

El-Rafey GA, Darwish SF. 2007. A PCR-RFLP assay to detect genetic variants of kappa-casein gene in cattle and buffalo. Arab J Biotech. 11:11-18.

FAO. 2013. Executive summary.country report supporting the preparation of the second report on the state of the world's animal genetic resources for food and agriculture,including sectorspecific data contributing tothe state of the world's biodiversity for food and agriculture. Rome (Italy): FAO.

El-Gawad MAM, Ahmed NS. 2011. Cheese yield as affected by some paramters review. Acta Sci Pol Technol Aliment. 10:131-153.

Gangaraj DR, Shetty S, Govindaiah MG, Nagaraja CS, Byregowda SM, Jayasankar MR. 2008. Molecular characterization of kappa-casein gene in buffaloes. Sci Asia. 34:435-439. DOI: 10.2306/scienceasia 1513-1874.2008.34.435.

Ghafoor A, Riaz MN, Zahur AB, Abbas N, Yousaf M, Shah A, Ishaq R, Suleman M. 2014. K-CN gene polymorhism in Nili-Ravi buffalo, Achai and Sahiwal cattle of Pakistan. Inter J Dairy Technol. 67. DOI: 10.1111/1471-0307.12146.

Gouda ME, Galal MKH, Abdelaziz SA. 2013. Genetic variants and allele frequencies of kappa casein in Egyptian cattle and buffalo using PCR-RFLP. J Agric Sci. 5:197-203. DOI: 10.5539/jas.v3n4p203.

Grosclaud F. 1988. Le polymorphisme genetique ded principales lactoproteins bovine. INRA Prod Anim. 1:5-17.

Khaizaran ZA, Al-Razem F. 2014. Analysis of selected milk traits in Palestina Holstein-Friesian cattle in relation to genetic polymorphism. J Cell Anim Biol. 8:74-85.

MacEachern S, McEwan J, Goddard M. 2009. Phylogenetic reconstruction and the identification of ancient polymorphism in the Bovini tribe (Bovidae, Bovinae). BMC Genomics. 10:177. DOI: 10.1186/1471-2164-10-177.

Mitra ASP, Krause I, Blusch J, Werner T, Balakrishnan CR, Pirchner F. 1998. Kappa-casein polymorphism in Indian dairy cattle and buffalo: A new genetic variant in buffalo. Anim Biotechnol. 9:81-87.

Montgomery GW, Sise JA. 1990. Extraction of DNA from sheep white blood cell. New Zeal J Agric Res. 33:437-441.

Othman EO, Zayed FA, El Gawead AA, El-Rahman MRA. 2011. Genetic polymorphism of three genes associated with milk trait in Egyptian buffalo. J Genet Eng Biotechnol. 9:97-102.

Pandey GS, Voskuil GCJ. 2011. Manual on milk safety, quality, and hygiene. Lusaka (Zambia); Golden Valley Agricultural Research Trust.

Patel RK, Chauhan JB, Singh KM, Soni KJ. 2007a. Allelic frequency of kappa-casein and betalactoglobulin in Indian crossbred (Bos taurus $\times$ Bos indicus) dairy bulls. Turk J Vet Anim Sci 31:399-402.

Patel RK, Chauhan JB, Singh KM, Soni KJ. 2007b. Genotype and allele frequencies of k-casein and $\beta$-lactoglobulin in indian river buffalo bulls (Bubalus bubalis). Buffalo Bull. 26:63-66.

Rachagani S, Gupta ID. 2008. Bovine kappa-casein gene polymorphism and its association with milk production traits. Genet Mol Biol. 31:893-897. DOI: http://dx.doi.org/10.1186/14712156-7-31.

Reinhardt TA, Lippolis JD, Nonnecke BJ, Sacco RE. 2012. Bovine milk exosome proteome. J Protem. 75:1486-1492. 
Ren DX, Miao SY, Chen YL, Zou CX, Liang XW, Liu JX. 2011. Genotyping of the k-casein and $\beta$-lactoglobulin genes in Chinese Holstein, Jersey and water buffalo by PCR-RFLP. J Genet. 90:e1-e5.

Riaz MN, Malik NA, Nasreen F, Qureshi JA. 2008. Molecular marker assisted study of kappacasein gene in Nili-Ravi (buffalo) breed of Pakistan. Pak Vet J. 28:103-106.

Shende TC, Sawane MP, Pawar VD. 2009. Genotyping of Pandharpuri buffalo for k-casein using PCR-RFLP. Tamilnadu Anim Sci. 5:174-178.

Susilorini TE, Sawitri ME. 2007. Produk olahan susu. Depok (Indonesia): Penebar Swadaya.

Tamil Nadu Agricultural University. 2009. Milk production: Lactation and milk yield [internet]. [cited 11 April 2016]. Available from: http://agritech.tnau.ac.in/animal_husbandry/animhus _buffalo\% 20milking.html.

Dogru U, Ozdemir M, Ercisli S. 2008. Genetic polymorphism in kappa-casein gene detected by PCR-RFLP in cattle. J Appl Anim Res 33:65-68. 